\title{
The Portuguese internal colonization: the country that could have been, but it was not
}

\author{
Miguel Moreira Pinto ${ }^{1,1}$, Joana Couto ${ }^{1}$ \\ ${ }^{1}$ Centro de Estudos Arnaldo Araújo, CEAA/CESAP, Porto, Portugal
}

\begin{abstract}
The policies of internal colonization played a fundamental role in the nation-state building process, as well as in the transformation of the rural landscape. In Portugal, the colonization of common lands (baldios) had the objective of increasing agricultural production, to stop the proletarianization of agrarian communities, encouraging small family farming, and land-ownership. Although already proposed at the end of the $19^{\text {th }}$ century, this process of rural colonization was further implemented in the 1940s and 1950s, the period in which a small number of Agricultural Colonies were built. While such process had produced new landscapes that can be regarded today as a cultural and architectural heritage, they remain poorly known and poorly recognized as such. This paper intends to reflect about the models of internal colonization defined in the scope of the political and ideological framework of the Estado Novo fascist regime. Based on different types of sources, it aims to better understand the significance of these rural landscapes as urban and architectural experiments, as well as to contribute to the identification of such settlements as relevant elements of the Portuguese cultural patrimony. Our conclusions do not fail to take into account the modest scale of the colonizing project undertaken by the Portuguese State when compared, for example, to what happened in Spain and Italy. Far below from what was initially planned and conceived, the construction of only 7 Agricultural Colonies can only be seen as trial run for a much larger agrarian reform that never came - the country that could have been, but it was not - taking the rural settlement of Pegões as a model.
\end{abstract}

\section{Introduction}

One of the more disturbing images of the internal colonization in Portugal results from a comparison with the Spanish case study. Considering the seven Portuguese agricultural settlements and the approximately three hundred agricultural settlements established in Spain -along the river basins of the Tejo, Guadiana or Guadalquivir- it would appear that the Portuguese initiative was a complete failure. Was this actually the case? To what extent was the Portuguese Junta de Colonização Interna (Internal Colonization Board) $(\mathrm{JCl})$ unable to obtain the results achieved by the Spanish Instituto

\footnotetext{
${ }^{1}$ Corresponding author: m.moreirapinto@gmail.com
} 
Nacional de Colonización (National Institute of Colonization)? What were the goals and responsibilities of the $\mathrm{JCl}$ ? What did it intend and/or fail to achieve?

While not claiming to offer a definitive analysis, this short paper seeks to contribute to an understanding and assessment of the successes and failures of the process of colonization of Portuguese rural landscape within the political-ideological context of the Estado Novo Fascist regime (1933-1974). Our analysis is centred on the studies and interventions carried out by the Junta in three distinct territories: (1) baldios (common lands), (2) lands benefitting from hydro-agricultural development works and (3) dry farming lands in the south of the country.



Figure 1: Map of agricultural colonies built in the Iberian Peninsula.

(based on: [1])

\section{Common lands}

Created in 1936 during the reorganization of the Ministry of Agriculture ${ }^{2}$, the $\mathrm{JCl}$ was tasked with mapping and determining the best use of baldios and uncultivated lands in the entirety of the national territory. Although a secondary objective within the Junta's colonization policy, this assignment would come to end decades of indecision and debate on the matter of common lands. Since the $19^{\text {th }}$ century countless legislative proposals and sporadic initiatives had sought to monetize these lands, which were especially numerous north of the Tejo, but whose size and agricultural potential had yet to be determined.

${ }^{2}$ Decree-Law $n^{\circ} 27207$ (1936). 
Consequently, the Reconhecimento dos Baldios do Continente (Survey on common lands on the continent), published in 1939, finally revealed the total area of these plots $(407,543 \mathrm{ha})$, their geographic distribution, and the percentage appropriate for agriculture (18.5\%) and that for afforestation (81.5\%). It was based on this survey that in 1941 the Plano Geral de Aproveitamento dos Baldios Reservados (General plan for the use of reserved baldios) (PGABR) was devised (with some alterations), and it was also based on the same survey that throughout the 1940s the Direcção Geral dos Serviços Florestais e Aquícolas (Directorate general of forestry and fisheries services) (DGSFA) hastened to include thousands of hectares of common lands (237,345 ha) spread across the districts of Bragança, Vila Real, Viana do Castelo, Coimbra, Guarda and Viseu - into its efforts of afforestation.

In line with legislation from $1938^{3}$, this afforestation attempt, which occurred at a scale unprecedented in Portugal's modern history, led to one of the most radical transformations of Portuguese agrarian landscape in which meadows and hills, previously the domain of herds of sheep and goats, were replaced by expansive tracts of woodland, that blocked the passage of livestock. Under the technical claim of combating soil erosion and the goal of securing the supply of raw materials required by the industrial sector, this transformation was far from unproblematic, and immediately elicited the strong opposition and resistance of the highland populations whose subsistence depended on the common lands. Traditionally, these lands provided the pasture necessary for keeping livestock, as well as the wood, the clay, the production of honey, the coal and the firewood with which local residents warmed themselves in winter. Divested of and blocked from using these plots, local communities became indignant. Conflicts between them and the forest service would, in some cases, turn to outright popular revolt quelled only by police repression ${ }^{4}$.

Eventually leading to migration and the desertion of the rural areas, the Estado Novo policies pertaining to the common lands were neither new nor original. Already during the I Republic (1910-1926) and the liberal monarchy, communal property and the baldios were considered antiquated, obsolete and underexploited spaces that should be seized in the name of progress and national economic development. While the regime sought the appropriation, sanitation and civilization of this territory, we may distinguish, within the governmental structure, the different positions and approaches of the DGSFA and the JCl. Though for the DGSFA, every property that was not private ought to be promptly delimited and afforested, the $\mathrm{JCl}$ acted more cautiously in the defense of local communities, reserving for itself the colonization of ever more extensive areas, with the aim of moderating the more ambitious goals of forestry engineers.

It must be noted that for the Junta, the colonization of these lands did not necessarily include the formation of agricultural colonies -in large part, the colonies it did establish served primarily as test cases for the actual colonization required in places with a population deficit and an abundance of arable land. The intervention of the $\mathrm{JCl}$ in the baldios served mainly to discipline and rationalize the use of common lands, promoting the division and privatization of these areas, and their individual distribution to those already using them. While this approach obviously generated less conflict than that of the expropriation undertaken by the DGSFA, the colonizing policies of the $\mathrm{JCl}$ in the Portuguese baldios entirely failed to achieve its stated aims. Evidence of this can be found in the implementation of the maps published as annexes to Decree-Law $\mathrm{n}^{\circ} 36054$, of 1946 , which show the first lands to be intervened upon by the PGABR.

\footnotetext{
${ }^{3}$ Law $n^{\circ} 1971$ (1938). [establishes the bases of afforestation].

${ }^{4}$ This revolt is the theme of the novel Quando os Lobos Uivam (When wolves howl) by Aquilino Ribeiro, 1958. Its publication was censured and the author was charged with a crime.
} 
During this phase, the area to be colonized (100,973 ha) included $53 \%$ of the common lands of those covered by the plan (190,552 ha) - the largest areas included Barroso $(35,593 \mathrm{ha})$ and Soajo (20,083 ha). The legislation presupposed the construction and distribution of $\mathbf{5 9 2}$ casais agrícolas (agricultural homesteads) throughout the baldios in Chã (55), Alvão (25), Montalegre, Padornelos and Meixedo (22), Morgade, Cervos and Beça (57), Barroso (183), Soajo (82), Boalhosa (83), Extremo (15), Serra da Ordem (16) and Lombadas (54). A significant part of this territory (41,433 ha) remained or were destined to the regime of communal management, but the principal part and the most distinctive colonizing initiative is that which pertains to the division and allocation of 26,448 glebas (plots of land) suitable for forestry and agriculture. In this manner, the $\mathrm{JCl}$ sought the division of an important section of the Portuguese landscape where there previously existed no walls or enclosures.

The application of this plan would, however, lead to successive reassessments and amendments concerning both the family farming there established and the actual subdivisions of land. A good example of what happened in other cases was the Projecto de Colonização dos Baldios do Extremo (Colonization project for the baldios of Extremo), of 1947, which, following a more detailed analysis, arrived at the conclusion of "the economic unviability of establishing agricultural homesteads" thus leading to most of the land - distributed among the parishes of S. João da Portela, Extremo and Santo André da Portela, in the municipalities of Monção and Arcos de Valdevez-being either divided or submitted to afforestation. Having terminated the overhaul of the Agricultural Colony of Milagres (1937-1940) and the project of Martim Rei (1938-1943) - colonies built on common lands whose homesteads were not included in previous legislation - throughout the 1940s and 1950s, the $\mathrm{JCl}$ at last commenced work on the Agricultural Settlements of Barroso (1943-1951), Alvão (1945-1954) and Boalhosa (1939-1958) and accomplished the organization of the common lands in different districts across the country. In the beginning and middle years of the 1960s the final tally was thus:

Table 1: chart of planned agricultural homesteads

\begin{tabular}{|l|c|c|c|}
\hline $\begin{array}{l}\text { Agricultural Colony: } \\
\text { Municipality }\end{array}$ & $\begin{array}{c}\text { homesteads } \\
\text { built }\end{array}$ & $\begin{array}{c}\text { homesteads } \\
\text { occupied }\end{array}$ & $\begin{array}{c}\text { homesteads average } \\
\text { area (hectares) }\end{array}$ \\
\hline $\begin{array}{l}\text { Milagres: } \\
\text { Leiria }\end{array}$ & 13 & 11 & 15 \\
\hline $\begin{array}{l}\text { Martim Rei: } \\
\text { Sabugal }\end{array}$ & 39 & 37 & 10 \\
\hline $\begin{array}{l}\text { Barroso: } \\
\text { Montalegre, Boticas }\end{array}$ & 132 & 114 & 20 \\
\hline $\begin{array}{l}\text { Alvão: } \\
\text { Vila Pouca de Aguiar }\end{array}$ & 25 & 24 & 8 \\
\hline $\begin{array}{l}\text { Boalhosa: } \\
\text { Paredes de Coura }\end{array}$ & 30 & 10 & - \\
\hline Total & 239 & 196 & 25 \\
\hline
\end{tabular}


Table 2: chart of allocated plots of land

\begin{tabular}{|l|c|c|c|}
\hline Districts & $\begin{array}{c}\text { number of baldios } \\
\text { divided }\end{array}$ & $\begin{array}{c}\text { number of plots } \\
\text { created }\end{array}$ & $\begin{array}{c}\text { number of families } \\
\text { benefitted }\end{array}$ \\
\hline Aveiro & 1 & 318 & 318 \\
\hline Bragança & 11 & 255 & 244 \\
\hline Faro & 7 & 756 & 752 \\
\hline Guarda & 3 & 1190 & 1190 \\
\hline Leiria & 2 & 407 & 355 \\
\hline Portalegre & 1 & 504 & 504 \\
\hline Vila Real & 17 & 1934 & 1221 \\
\hline Viseu & 4 & 502 & 496 \\
\hline Viana do Castelo & 3 & 383 & 367 \\
\hline Coimbra & 2 & 1590 & 1578 \\
\hline Total & $\mathbf{5 1}$ & $\mathbf{7 8 3 9}$ & $\mathbf{7 0 2 5}$ \\
\hline
\end{tabular}

Considering these numbers, if we compare the number of planned casais agrícolas and, in particular, the number of glebas planned under the Decree-Law of 1946 with what was actually implemented over two decades, our conclusion cannot be different from that reached by João Antunes Estevão:

"The colonizing policy of the Junta in the baldios of the north and the centre of the country was a total failure". The few colonies that were established, while perhaps interesting from the point of view of agricultural experience and of landscape intervention, soon came to be "seen as genuine 'curiosities' - veritable relics of the past - in spite of the efforts of social engineering and the important studies undertaken by the $\mathrm{JCl}$ technicians of the time" [2].

\section{Lands benefitting from hydro-agricultural development works}

Of the first missions and responsibilities of the $\mathrm{JCl}$ at the time of its establishment are the following, in order of priority: " 10 taking possession of the lands transferred to it by the Junta Autónoma das Obras de Hidráulica Agrícola (Autonomous Board for Agricultural Hydraulics Construction) (JAOHA, established in 1931); $2^{\circ}$ establishment of casais agrícolas in accordance with agronomic, economic and social studies; $3^{\circ}$ promote the creation of associations of irrigators and the establishment of agrarian posts". Significantly, the survey and reservation of the baldios of the State, together with the authorization to purchase "other land put up for sale which should be used for colonization", were only described in the subsequent paragraphs ${ }^{2}$.

Aimed at increasing and diversifying the national agricultural production, the conversion of land used for dry farming into irrigated land that was undertaken under the regulations published in $1937^{5}$ and $1938^{6}$ occurs at a slow pace during the period of the II World War and only at the end of 1940 are the first infrastructures completed. Anticipating the conclusion of these works, the same plan approved by the Decree-Law $\mathrm{n}^{\circ} 36054$ already included the project of Campina da Idanha which was to initiate a vast

\footnotetext{
${ }^{5}$ Law $n^{\circ} 1949$ (1937). [establishes the responsibility of the State in investigation and undertaking works of hydro-agricultural development and enacts the bases for this purpose].

${ }^{6}$ Decree-Law $n^{\circ} 28652$ (1938). [enacts a number of regulations relative to the works undertaken by the JAOHA].
} 
process of internal colonization in the guise of the large irrigation works of the United States and Italy, and similar to what would be developed in Spain.

Divided into two phases, the draft project of Idanha included the farming of 7,431 ha of land $(1,957+5,474)$ and the construction of 320 agricultural homesteads. However, the full use of this and other areas - Vale do Sado, Burgães, Alvega and Loures, Paul da Cela, Paul de Magos, Campilhas, Caia, Roxo, Mira and Sorraia [3] - required the expropriation of private plots located in the vicinity of irrigation systems. While such a proposal is indeed put forward in 1953, it is immediately met with opposition by the Câmara Corporativa (Corporative Chamber) ${ }^{7}$, a majority of representatives in the Assembleia Nacional (National Assembly) and the large landowner and farmer organizations that constituted an important base of support for the Estado Novo. Among the arguments submitted was that internal colonization had not yet proven to be a mature and economically viable option. Further, the payments required to appropriate private lands would lead to the skyrocketing of costs in an already expensive colonization operation that had not been planned to undertake this additional financial burden.

In 1960, though industrialization and the expansion of the Portuguese economy were emphasized while agriculture continued to have the lowest productivity rates in all of Europe, the government published a new legal framework for internal colonization that asserted the same principles operating in irrigation areas. This time, however, rejection would be even more violent and categorical ${ }^{8}$. The reasons put forward were old and new, even far-fetched, though the principal point of contention remained the same: the possibility of resorting to expropriation, seen by some to be "dispossession" and "pillage", and an inadmissible attack on the sacred and inviolable principle of private and individual property.

Though not the only causes, these two episodes are symptomatic of the gradual departure from the vision of a true colonization led by the State and understood as a means of transforming and reforming land ownership. While the $\mathrm{JCI}$ never discontinued the studies aimed at improved capitalization of the works undertaken by the JAOHA, the final assessment, written by Eugénio de Castro Caldas, could hardly have been more discouraging:

Never was colonization permitted to occur in the lands which had benefitted from hydroagricultural development. As soon as the first large project was finished in Idanha - considered regionally as the driver of progress - the implementation of laws was blocked. The land of Ladoeiro celebrated the water...but not a single settler was moved to the areas that were to be irrigated...Rent payments were received and nothing changed... No settlers, no villages, no renewed human communities were established in the irrigated areas of the south. Yet such fields symbolized a monumental investment for which all Portuguese had contributed. Many landowners sold the developed lands and enriched themselves... with capital gains, or they charged additional rent... The hopes and dreams of hydraulic engineers in developing this project of social importance were never realized [4].

\section{Dry farming areas in the south of Portugal}

Apart from the Campina of Idanha, the maps included in the same 1946 Decree-Law reference the colonization projects in Gafanha (Ílhavo) and Pegões (Montijo), which were to be undertaken in lands that were State property. In the first case, the project

\footnotetext{
${ }^{7}$ Diário das Sessões (1953). Report n 3/VI, Draft Law n 3. December 16.

${ }^{8}$ Actas da Câmara Corporativa (1960). Report n 29/VII, Draft Law n 510 . March 30.
} 
existed as part of the attempts to develop farmland in the sandy soils on coastal plots of land (Aguçadoura and Apúlia, Gafanha and Vila Real de Santo António). The poor results of this trial would impede the construction of the second phase of the project in which there were 451 additional planned agricultural homesteads over three villages ${ }^{9}$. Of the original Agricultural Colony (1942-1952), with 75 casais agrícolas, merely one half would be occupied.

On the contrary, the case of Pegões (1942-1952) was the most successful of the colonization plans developed by the $\mathrm{JCl}$. In operation to this day, it is also the case that generates the most curiosity and academic interest, as well as the biggest concerns for the classification and preservation of its heritage. Taking up nearly $50 \%$ of the farmland in all the national Agricultural Colonies, this project was planned, from its inception, as an exemplary intervention. Established in the Rovisco Pais estate, on the border between the districts of Setúbal and Évora, the colony was divided into four settlements: Faias (57 casais agrícolas), Pegões Velhos (99), Vale da Judia (8) and Figueiras (50). Generally, each homestead included irrigated land, land for dry farming, and a third plot destined for grapevine. While the first three settlements were organized according to existing waterways, the creation of an irrigation system led to the more regular and geometric division of plots that characterized the settlement of Figueiras [5]. The construction began in 1947 and the first settlers arrived in 1952. Support and technical structures were finalized in later years, as well as the social centres of Faias and Pegões Velhos (including a church, school, medical centre, etc.). On the subject of this model-colony, Castro Caldas unambiguously stated:

It was a thorn in the conscience of the large landowner and farmer. lgnoring it, hoping that the initiative would end in a spectacular disaster, leaving an exemplary ruin that the winds would bury into the sandy ground... [where] the largest estates in the country were located...in the middle of a monotonous 'Pliocene', deserted due to the large size of the property, Pegões emerged as a strange attempt proving that the desert could be transformed into a country [4].

In general, the Agricultural Colony of Pegões represented precisely that: an exceptional and unique testing ground which functioned as a pilot for the most urgent rectification of land ownership that consisted in the division and colonization of the large tracts of land in the Alentejo ${ }^{10}$ where the surplus highland populations could be settled. This initiative -an authentic agrarian reform- is, already at its inception, considered by $\mathrm{JCl}$ technicians and leaders to be a fundamental priority ${ }^{11}$. In the words of the then president of the Junta:

"We should, without a doubt, initiate a policy of land division in the area south of the Tejo, such a project should be undertaken with the utmost prudence and be based on a deep understanding of the possibilities of the lands and plots". The colonization works completed in the baldios were considered insufficient, so that it was necessary to "spread, in the various regions of the country, and particularly those dominated by large

${ }^{9}$ Diário das Sessões (1956). Report n 43/VI, Gafanha (II Parte). July 7.

${ }^{10}$ This idea is made obvious in a text on internal colonization published by the Secretariado Nacional de Informação (National Secretariat of Information): "Having undertaken the necessary studies for the development of colonization projects in the Pegões estate and the municipality of Moura...the JCl faced the largest problem of the colonization of the extensive areas of dry farming in the south. Such works had gathered enough data to permit reaching some conclusions and thereby beginning the complex task of colonizing the Alentejo peneplain" [6: 59].

${ }^{11}$ The "studies on the possibilities of colonization of the dry farming lands of the south" are among the various Work Reports and Management Accounts of the JCl during the 1930s and 1940s and are still the theme of a publication, in 1943 [7]. 
property, agricultural settlements which would permit setting up a number of families within agricultural homesteads". In order to achieve that goal, it was estimated that an area of approximately 800,000 ha, between the Alentejo and the Algarve, was appropriate for colonization, permitting the settlement of "forty thousand families... approximately, in small autonomous farming operations", each with an average area of 20 ha [8].

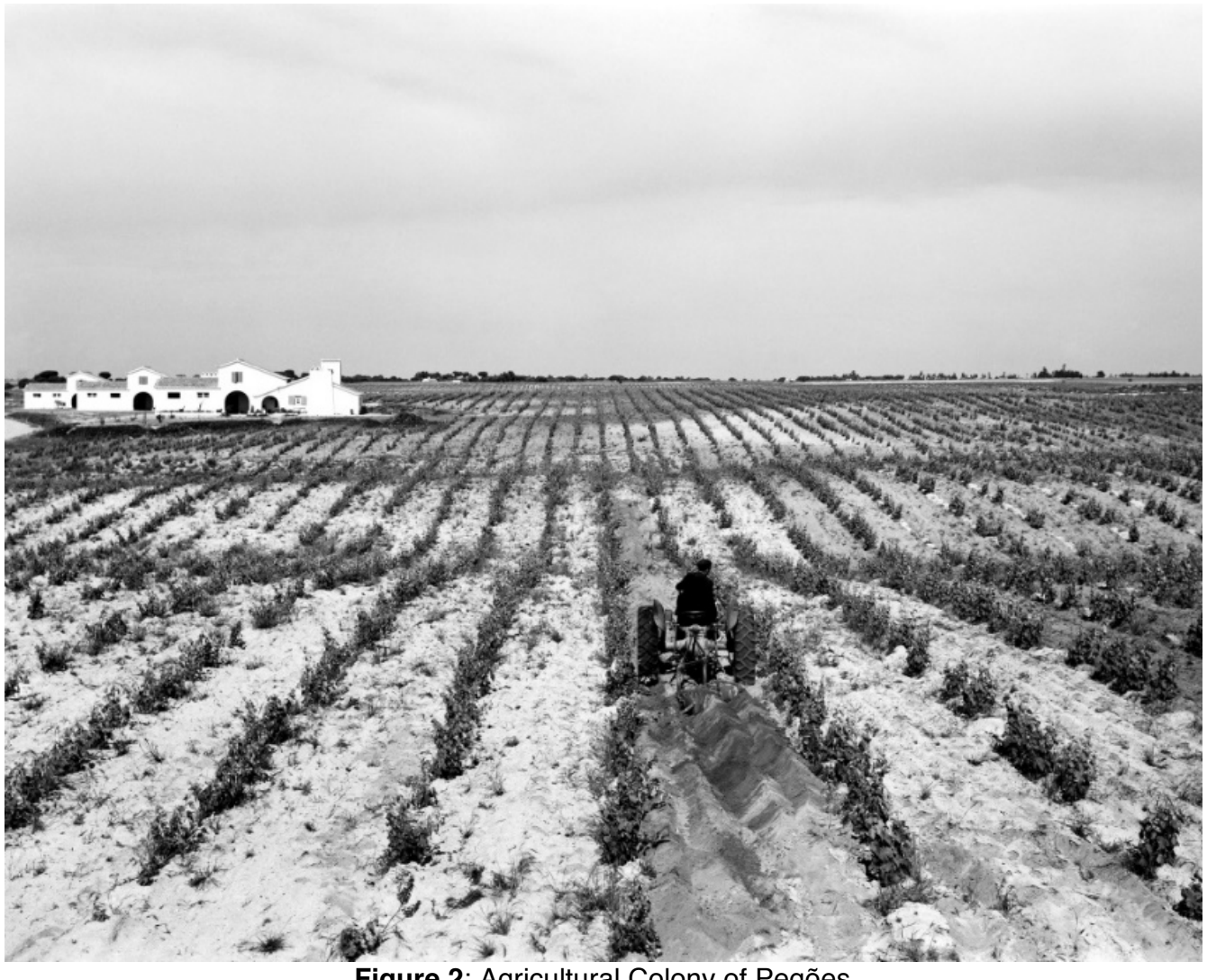

Figure 2: Agricultural Colony of Pegões

[Photo: Mário Novais. Source: @ Calouste Gulbenkian Foundation]

Of all the studies that the $\mathrm{JCl}$ was unable to or impeded from doing this was undoubtedly the most striking for its utopian vision, the scale and size of the numbers, and the impact that it obviously would have had on Portuguese rural life and landscape.

\section{Concluding remarks}

In this short summary we wanted to focus on the three principal spheres of action in which the work of the $\mathrm{JCl}$ could have made a difference -but it didn't. Hampered as it was in key moments, namely during the first Planos de Fomento (5 years development plans) of the $1950 \mathrm{~s}^{12}$, when a window of opportunity opened for the establishment of its boldest projects, the internal colonization in Portugal would remain, merely, a good

\footnotetext{
${ }^{12}$ Law $n^{\circ} 2058$ of 1952 and Law $n^{\circ} 2094$ of 1958 corresponding, respectively, to the first and second development plans, enacted the bases for the implementation of the investment plans of the years 1953-1958 and 1959-1964.
} 
intention. Unable to promote settlement in lands held by the Junta itself - in Reguengos de Monsaraz, Serpa, Elvas and Santiago do Cacém - it would thus be less in colonizing efforts and rather in the specific, concrete and local context of the Melhoramentos Agrícolas (Agricultural Improvements) ${ }^{13}$ that the intervention of the $\mathrm{JCl}$ would be most successful. This programme included technical as well as financial assistance to which individual farmers, cooperatives or guilds could apply in order to install water collection systems, perform land drainage and soil conditioning, construction, equip and improve agricultural facilities, sowing seed and planting trees, construction of houses, warehouses, granaries and wineries, acquiring machinery and tools, etc. With an everwidening range of action, the $\mathrm{JCl}$, in summarizing its work of 25 years, described its activity until the beginning of the 1960 s thus:

The creation of the Junta stemmed from the need to solve the problem of settlement in the interior. To this mission was later added the support for upgraded conditions through the distribution of low-interest rate credit options to the landowners who requested it. Lately, its operations have come to include the study of property structures and types of farming, land use contracts (rentals, partnerships), rural well-being, etc. As such, the work of the Junta has been characterized by the persistent and continuous elaboration of surveys and studies which was combined with a policy of implementation, when legal and financial means have allowed it [3].

The research and studies undertaken by the $\mathrm{JCl}$ were, in reality, as important and sizeable as was the level at which they were ignored. Without the political support and the necessary legal and financial means, it would be impossible for the Junta to realize its more ambitious plans which, in any case, were unlikely to have succeeded in preventing the extensive migration away from rural areas at a time in which it had become obvious that these population shifts would not be reversible by projects of internal colonization alone. In period when there was already an understanding about the need for cities to become more rural and for rural areas to become more urbanized [9], the settling of populations was instead dependent on a structured and coherent conceptualization of the country as a whole, of planning on a regional scale, together with an articulated and integrated economic, industrial and agricultural policy that remained unfulfilled. And this, then, was perhaps the country that could have been, but never was.

\section{Acknowledgements}

This work was conducted under the project MODSCAPES - Modernist Reinventions of the Rural Landscape (HERA.15.097). This project has received funding from the European Union's Horizon 2020 research and innovation programme under grant agreement $N^{\circ} 649307$

\section{Short Resume}

Miguel Moreira Pinto, Architect (ESAP, 1996), MSc in Architecture (UL Porto, 2011), PhD candidate (ETSAV/Universidad de Valladolid). Since 2010, team member of the Architectural Studies research group of CEAA/CESAP, Escola Superior Artística do Porto, taking part in R\&D projects such as: "Photography, Modern Architecture and 'Escola do Porto': Interpretations on

${ }^{13}$ Law $n^{\circ} 2017$ (1946). [establishes the grounds on which State support for agricultural improvements must be based]. 
Teófilo Rego Archive" (2014/2015). Research fellow of the project MODSCAPES: Modernist Reinventions of the Rural Landscapes (HERA.15.097).

Joana Couto, Architect (UL Famalicão, 2003). Since 2010, team member of the Architectural Studies research group of CEAA/CESAP, Escola Superior Artística do Porto, taking part in R\&D projects such as: "Southern Modernisms" (2014/2015). Research fellow of the project MODSCAPES: Modernist Reinventions of the Rural Landscapes (HERA.15.097).

\section{References}

1. PAREDES, A.; MALDONADO, J. 1991. Historia y Evolución de la Colonización Agraria en España: La Planificación del Regadío y los Pueblos de Colonización, vol. 3, Madrid, MAP/MAPA/MOPT.

2. ESTEVÃO, J. 1983. "A Florestação dos Baldios", Análise Social ( $3^{\text {rd }}$ series), vol. 19, $\mathrm{n}^{\circ}$ 77-78-79: 1157-1260. Retrieved from: http://analisesocial.ics.ul.pt/documentos/1223466126E7mAX8tz1Mh41FR6.pdf [available on $7 \%$ arch 2019].

3. MINISTÉRIO DA ECONOMIA, JCI, 1962. Referências da Imprensa. April 24.

4. CASTRO CALDAS, E. 1998. A Agricultura na História de Portugal, Lisbon, EPN.

5. GUERREIRO, F. 2015. Colónias Agrícolas Portuguesas construídas pela Junta de Colonização Interna entre 1936 e 1960, PhD diss., Faculdade de Arquitectura da Universidade do Porto.

6. Colonização Interna (s.d. - 1940s). (Cadernos do Ressurgimento Nacional), Lisbon, SNI.

7. CALDAS, J. G. P. et al. (eds.) 1943, Problemas de Colonização - A Zona Pliocénica ao Sul do Tejo (Problems of colonization - the Pliocene area south of the Tejo), Ministério da Economia, JCl.

8. MINISTÉRIO DA ECONOMIA, JCI. 1948. Notas sobre a crise do desemprego rural $e$ as possibilidades de colonização do Sul (Notes on the crisis of rural unemployment and the possibilities of colonization in the south).

9. ANDRESEN, J. 1961. Para Uma Cidade Mais Humana, Porto, Imprensa Social. 